\title{
REGIONALNO IN PROSTORSKO PLANIRANJE ALI REGIONALNO - PROSTORSKO PLANIRANJE
}

\author{
Milan Naprudnik \\ Soška ulica I 7 b, SI-I000 Ljubljana
}

Pregledni znanstveni članek

COBISS 1.02

\section{Izvleček}

V 60-tih letih prejšnjega stoletja se je pokazala nujnost povezovanja različnih vidikov sektorskega planiranja, razvilo se je regionalno-prostorsko planiranje. V Sloveniji so bile v obdobju 1970-1975 izdelane strokovne osnove za sprejem regionalno-prostorskega plana republike. S prehodom na sistem družbenega planiranja so se sprejemale le splošne usmeritve, ker se je nadaljevalo še 10 let v samostojni državi. Šele v letu 2002 je bila sprejeta Strategija prostorskega razvoja, pri tem pa niso bila razčiščena razmerja z strategijo regionalnega razvoja, strategijo razvoja na državni ravni in usmeritvami na evropski ravni.

Ključne besede: strategija razvoja, regionalno planiranje, urejanje prostora, evropske smernice, zakonodaja, geografija.

\section{REGIONAL AND SPATIAL PLANNING OR REGIONAL-SPATIAL PLANNING}

\begin{abstract}
On the basis of necessities to connect different aspects of sectoral planning in the 60-ies of last century, regional-spatial planning was developed. In 1970 -1975 Slovenia elaborated basic professional elements for adoption of regional-spatial plan of the republic. With the transition to the system of social planning a process of general guidance were adopted, which were also continuing for ten years in the time independent state. Strategy of spatial development was adopted not until the year 2002, but without clarifying the relationships between the strategy of regional development at the national level and with the guidelines at the European level.
\end{abstract}

Key words: development strategy, regional planning, spatial management, European guidelines, legislation, geography. 


\section{UVOD}

$\mathrm{Na}$ srečanju naj bi si pojasnjevali kako poteka naše planiranje v teoriji in praksi. O teoriji in o vlogi geografov ni kaj dodati, o tem govorijo raziskovalni dosežki, izdane publikacije in visok mednarodni ugled. Kako pa v praksi? Zgodilo se je 5. nov. 1973 v gradu Brdo pri Kranju. Skupščina SR Slovenije je že sprejela izhodišča za pripravo regionalno-prostorskega plana SR Slovenije (Poglavitni smotri in smernice za urejanje prostora) in na teh osnovah je Zavod SR Slovenije za regionalno-prostorsko planiranje pripravil prvi planski element »Zasnove urbanizacije SR Slovenije«, zasnovan na policentričnem razvoju ter ga objavil v razpravo. V gradivu je bilo med drugim opredeljeno, da bo prihodnjo vlogo Kranja potrebno presojati tudi v odnosu do Zg. Gorenjske, predvsem pa do Ljubljane, s katero bi po dogovoru Kranj razvil nekatere oskrbne storitve. Sledilo je vabilo na zasedanje medobčinskega sveta gorenjskih občin (regije). Predsednik sveta in hkrati predsednik Skupščine občine Kranj Franc Šifkovič je pozdravil zbrane, potem pa zaklenil vrata svečane dvorane, kjer je potekalo zasedanje, rekoč, da se ne bomo razšli, dokler predlagatelji ne prepričajo predstavnike občin o utemeljenosti razcepa gorenjske regije. Bilo je obdobje začetkov samoupravljanja, a po osmih urah razlag in ugovorov je predsedujoči le zaključil zasedanje z napovedjo, da bodo gorenjske občine vztrajale na povezovanju le v okviru Gorenjske regije, da pa hkrati spoštujejo visoko raven pojasnjevanja predlagateljev gradiva. To priznanje je letelo na današnjega jubilanta, ki je $s$ stoično mirnostjo presajal teoretične zasnove v prakso, na trda tla regije.

To je bilo obdobje prodora geografov, ki so raziskovalne dosežke znali prenašati v razvojne programe na vseh ravneh. Vrišerju in Klemenčiču sta sledila Kokole in Jeršič, njima Ravbar in Černe, nadaljevali so njihovi študentje in vrata so ostala nezaklenjena. Iz vrste razlogov - o tem pozneje - včasih priprta.

\section{UREJANJE PROSTORA - sestavina nacionalnega planiranja}

Odkar ta svet stoji nekaj ugotavljamo, presojamo in načrtujemo. Vse pa se dogaja v prostoru, ki ga označujejo prirodne značilnosti, njegova raba in tudi administrativne meje.

Svet se je razvijal, prišlo je obdobje industrializacije, pretok prebivalstva iz podeželja $\mathrm{v}$ mesta, ki so se najprej zgostila in potem začela širiti, dobili smo prve tkim. sektorske plane, le-te je bilo potrebno povezovati in uveljavila so se tkim. nadsektorska planiranja z različnimi stopnjami ambicij in časovnih horizontov:

- ekonomsko planiranje (davčni sistem, potrošnja, družbeni proizvod)

- socialno planiranje (socialni sistem, družbeni standard...)

- urbanistično-prostorsko planiranje (urejanje mest in mestnih območij).

Pokazala se je potreba po povezovanju vidikov planiranja in v letu 1964 je Generalna skupščina Združenih narodov sprejela resolucijo o planiranju razvoja: »Zaradi pomembnosti združevanja lokacijskih faktorjev in faktorjev okolja z ekonomskimi in socialnimi činitelji razvoja je potrebno smatrati prostorsko planiranje skupaj z ekonomskim in socialnim planiranjem kot integralne dele nacionalnega planiranja. Sektorsko planiranje, ki zajema posamezne 
gospodarske in družbene dejavnosti pa se mora prilagajati okviru, ki ga dopušča nacionalna ekonomija v okviru politike regionalnega razvoja ter prostorskih (geografskih) pogojev« (Združeni narodi, 1964).

V II. polovici 60-tih let prejšnjega stoletja je v Evropi prodrlo spoznanje o nujnosti povezovanja mestnih in podeželskih območij in »zgodilo se je« regionalno-prostorsko planiranje in izkazala se je potreba po povezovanju na relaciji urejanje prostora in regionalni razvoj, ki ga je v Evropi usmerjala regionalizacija nacionalnih ekonomskih planov na območja subregij in regij. V letu 1973 se je odzvala Evropska konferenca ministrov, pristojnih za regionalno prostorsko planiranje in sprejela naslednjo definicijo za urejanje prostora:

1. „Fizično planiranje: na prvi ravni je UREJANJE PROSTORA politika sestavljena iz vsote ukrepov, katerih cilj je boljša izraba tal, kontrola in organizacija urbane ekspanzije, ustrezna bližina zelenih površin, pritegnitev tovarn v industrijske, posebej opremljene cone, usmerjanje razvoja turizma itd.

2. Regionalno planiranje: na drugi ravni se UREJANJE PROSTORA identificira $z$ regionalnim ekonomskim planiranjem. Njegov cilj je zagotoviti dvig življenske ravni v celotnem prostoru, manjšati regionalne neenakosti s tem, da omogoča razvoj zapostavljenih regij.

3. Planiranje organizacije prostora: na tretji ravni je UREJANJE PROSTORA politika, $s$ katero načrtujemo takšno razmestitev stanovanjskih, delovnih in oskrbnih zmogljivosti, da bi ljudem omogočili najboljše življenske pogoje, materialne in kulturne« (Evropska konferenca, 1973).

No preteklo je še eno generacijsko obdobje in po 30-tih letih je bilo potrebno postaviti nova pravila za področje načrtovanja, v svetovnem merilu sprejeta v Agendi 21 (Svetovna konferenca Združenih narodov o trajnostnem razvoju - Rio de Janeiro 1992), v evropskem pa v usmeritvah za prostorsko razvojno politiko v Evropi »Vodilna načela za trajnostni razvoj evropske celine« (Evropska konferenca ministrov odgovornih za regionalno planiranjeCEMAT, Hannover, 2000).

\section{RAZVOJ V SLOVENIJI-prepletanje prostorskega in regionalnega planiranja}

Prva zakonska določila so zadevala posege v prostor: Stavbni red za Vojvodino Kranjsko (1875), sledil je Gradbeni zakon Kraljevine Jugoslavije (1931), po drugi svetovni vojni Zakon o urbanističnem projektiranju (1958).

\section{Obdobje 1966-1975}

Vse večji posegi v prostor in vse večje razlike v razvitosti posameznih območij so narekovale, da je Skupščina SR Slovenije v letu 1967 sprejela Zakon o urbanističnem planiranju in Zakon o regionalnem prostorskem planiranju, ki je združeval prostorski in regionalni vidik in na njegovi osnovi program na izdelavo regionalnega-prostorskega plana. Na teh osnovah je takratna Skupščina SRS v letu 1973 sprejela Resolucijo o poglavitnih smotrih in smernicah 
za urejanje prostora Zavod SRS za regionalno prostorsko planiranje je na tej osnovi pripravil kot izhodiščni element plana »Zasnovo urbanizacije SRS«, ki ga je takratna vlada (IS SRS) v letu 1974 objavila v javno razpravo, kot temelj za uresničevanje policentričnega (regionalnoprostorskega) razvoja Slovenije z opredelitvami:

- razvojnih urbanih središč in njihovih vplivnih območij $(14 \text { regij })^{1}$

- kazalcev regionalnega razvoja (prebivalstvo, delovna mesta in družbeni proizvod po regijah)

- vpliva zasnove urbanizacije na planiranje infrastrukturnih sistemov (promet, energetika, vodno gospodarstvo) (Resolucija ..., 1973).

V tem obdobju je večina takratnih občin sprejela tudi občinske prostorske plane.

V letu 1971 smo dobili še zakon o pospeševanju razvoja manj razvitih območij v SR Sloveniji in tleti je začela dvotirnost na relaciji prostorski : regionalni razvoj.

\section{Obdobje |976-199|}

Z uvedbo sistema družbenega planiranja je Skupščina SRS leta 1976 sprejela prvi srednjeročni »Družbeni plan SRS za obdobje 1976-1980«, do leta 1990 sta sledila še dva. V letu 1986 je Skupščina SRS sprejela tudi Dolgoročni plan SRS za obdobje 1986-2000, med razvojne naloge je sodilo tudi poglavje strategija regionalnega razvoja in zasnova in strategija urejanja prostora, poselitve, varstva dobrin in okolja. Ta »izvirna« zvrst planiranja v obdobju samoupravljanja je združevala ekonomske, socialne in prostorske vidike, slednji so se izražali predvsem kot grafično-kartografska upodobitev kazalcev iz ekonomsko-socialnega področja. Na državni ravni so se sprejemale le splošne usmeritve, razvojne programe, ki so jim sledile investicijske odločitve (tudi za posege v prostor) pa so sprejemale samoupravne interesne skupnosti, ki so se financirale prek obveznih prispevkov.

\section{Obdobje 1992-2000}

S sprejetjem Ustave države Slovenije (1991) je bil ukinjen sistem družbenega planiranja, ekonomske ter socialne vidike so nadomestili razvojni programi sektorjev.

V letu 1993 Vlada RS razločila regionalno planiranje kot razvojno gospodarsko in prostorsko kot urejanje prostora in porajali so se novi zakoni za področje regionalnega razvoja $(1995,1999,2003)$ in za področje urejanja prostora (2002) - Državni zbor RS je zadolžil Vlado RS, da slednjega predloži v razpravo že v letu 1993.

Za regionalni (gospodarski) vidik je bila zadolžena Služba Vlade RS za strukturno politiko in regionalni razvoj, za prostorski vidik Urad za prostorski razvoj pri Ministrstvu za okolje, prostor in energijo, za gospodarski razvoj pa Urad Vlade za makro-ekonomske analize in razvoj.

In nastal je prazen prostor - ob odsotnosti novih razvojnih usmeritev na državni ravni sta Vlada RS oz. Državni zbor sprejela v obdobju 1993-1999 razvojne programe oz. strategije za vsa področja, ki posegajo v prostor in vplivajo na regionalni razvoj (kmetijstvo - 1993, turizem - 1995, gozdarstvo - 1996, energetika - 1996, promet - 1999).

\footnotetext{
${ }^{1}$ Usmeritve na ta razvojna središča oziroma regije so se prenašale v vse družbene plane po letu 1976 in so tudi osnova Strategij regionalnega (2001) ter Prostorskega razvoja Slovenije (2004).
} 


\section{NOVE STRATEGIJE RAZVOJA}

Po desetih letih podaljševanja že ukinjenih planskih usmeritev iz sistema družbenega planiranja so se »brez voznega reda« začele porajati nove razvojne usmeritve - strategije.

Državni razvojni program RS smo dobili leta 2001, opredeljen kot strateški gospodarski razvojni dokument, kiizhajaiz»koncepta trajnostnega razvoja-izenakovrednega obravnavanja gospodarske, socialne in okoljske razsežnosti blaginje kot svojega osnovnega cilja«. Nekaj je vprašljivo! Ciljni razvojni scenarij obravnava izključno makroekonomske vidike razvoja Slovenije, med razvojne prednostne naloge pa so poleg spodbujanja podjetniškega sektorja in konkurenčnosti, znanja, razvoja človeških virov in zaposlovanja uvrščene tudi naloge $s$ področij infrastrukture, gradnje stanovanj, prestrukturiranje kmetijstva in razvoja podeželja in tudi krepitve skladnega regionalnega razvoja, ki vključuje program razvoja mest in podeželja, razvoja naravne dediščine in regionalne infrastrukture. Navedeni so poglavitni prostorski elementi o celovitegm prostorskem razvoju pa ničesar. (Program je bil pripravljen na osnovi Zakona o javnih financah (Državni razvojni program ..., 2002).

Strategija regionalnega razvoja Slovenije 2001-2006 sprejeta prav tako v letu 2001, s povdarkom na skladnosti s Strategijo gospodarskega razvoja in navedbo, da je priprava potekala sočasno s pripravo »Prostorskega plana Slovenije« in tudi, da sta oba dokumenta vsebinsko vsklajena. Posebej je povdarjeno, da je spodbujanje razvoja regionalnih središč somestij v skladu s Prostorskim planom Slovenije, ki pa je bil sprejet šele tri leta pozneje (junij 2004) pod nazivom Strategija prostorskega razvoja Slovenije (Strategija ..., 2001).

Izhodišča se zaključujejo s navedbo, da »učinkovito izvajanje regionalne politike zahteva uvedbo pokrajin in novo teritorialno razdelitev pristojnosti med državo, pokrajino in občino« Strategija ..., 2001, str.5).

Strategija prostorskega razvoja Slovenije Končno; več kot deset let smo le dopolnjevali »napotke iz prostorske vsebine družbenih planov« in sestavin Dolgoročnega plana SRS za obdobje 1986-2000, kjer je bil prostorski vidik podrejen ekonomsko-političnim ciljem in tudi ekonomskim metodam načrtovanja in namesto sinteze strokovnih predlogov makrouporabnikov prostora (sektorjev in občin) smo imeli le sestavljanko prostorskih elementov.

V izhodiščih in ciljih tega »prvega« prostorskega (regionalno prostorskega) plana - če odpišemo Zasnovo urbanizacije Slovenije iz leta 1974 in prostorske sestavine v Dolgoročnem planu SRS za obdobje 1986 - 2000 - smo vendarle dobili dolgo pričakovane usmeritve. Prostorska strategija je skupaj s gospodarsko strategijo opredeljena kot krovni dokument za usmerjanje celovitega razvoja in osnova za vsklajevanje sektorskih politik. Opredeljuje območja nacionalnega in regionalnega pomena z kazalci demografskega, stanovanjskega, ekonomskega in socialnega - družbenega razvoja ter »podaja razvojne usmeritve za posamezne prostorske sisteme, poselitev, infrastrukturo in krajino ter določa ukrepe za njihovo izvajanje«. Moti, da je varstvo okolja, kot zadnja postavka v ciljih zreducirana na opremljanje zemljišč za gradnjo komunalnih naprav in na ravnanje z odpadki; vključevanje posameznih sestavin varstva okolja v načrtovanje prostorskega razvoja dejavnosti, ne zveni prepričljivo, ni ustrezne povezave z Nacionalnim programom za varstvo okolja, sprejetim tudi v letu 2004 na osnovi Zakona o varstvu okolja. Dobršen del programa za uresničevanje Zakona o varstvu okolja bi pridobil na teži, če bi bil vključen v »matično« strategijo. 
Vprašljiva pa je skladnost s Strategijo regionalnega razvoja Slovenije (SRRS), ki jo Strategija prostorskega razvoja Slovenije (SPRS) niti ne omenja, med cilje pa je uvrřčen skladen razvoj regionalnih območij. Obe strategiji sicer temeljita na enovitem poselitvenem modelu, regionalna prek spodbujanja razvoja regionalnih središč/ somestij, prostorska pa prek razvoja policentričnega omrežja mest. Prek regionalne naj bi se »spodbujal tudi prostorski odnos med mesti in podeželjem«, prek prostorske pa naj bi se »medsebojno dopolnjevale funkcije podežljskih in urbanih območij«. Tudi uvedba regij je identična, le da jih regionalna uvaja kot regije (Pomurska,...), prostorska pa z mesti in njihovimi vplivnimi funkcionalnimi območji ter kot pomembnimi regionalnimi prometnimi vozlišči. (Strategija ...., 2004)

Strategija razvoja Slovenije /junij 2005/ končno na vidiku - po pomenu - prvi strateški dokument, če odštejemo Državni razvojni program iz leta 2001, ki je bil naravnan izrazito gospodarsko. Nosilec tega krovnega dokumenta je Urad za makroekonomske analize in razvoj, čeprav sodi njegova priprava med temeljna delovna področja Službe za strukturno politiko in regionalni razvoj. Podane so razvojne usmeritve za področje gospodarskega in socialnega razvoja, in položaja Slovenije v mednarodni skupnosti, usmeritve za področja regionalnega, prostorskega in okoljskega razvoja pa so obdelane najmanj dvoumno:

- peta razvojna prioriteta "povezovanje ukrepov za doseganje trajnostnega razvoja« med usmeritve za »SKLADNEJŠI REGIONALNI RAZVOJ« vključuje tudi razvoj policentričnega urbanega sistema, kvalitetnejšo pripravo prostorskih aktov, poenostavitev prostorskih predpisov, zagotovitev oskrbe s čisto pitno vodo, tesnejše sodelovanje med mestnimi in podeželskimi območji, ukrepe za ohranjanje poseljenosti in kulturne krajine, boljšo prometno povezanost območij, kar je na osnovi določil Zakona o urejanju prostora vključeno v sprejeto STRATEGIJO PROSTORSKEGA RAZVOJA;

- med določili za »IZBOLJŠANJE GOSPODARJENJA S PROSTOROM« pa so vzpostavitev evidenc kmetijskih zemljišč in njihova zložba (komasacije) povečanje fonda stavbnih zemljišč, razvijanje nepremičninskega trga, tudi določila o spodbujanju poselitve v mestih, ki imajo med 7.000 do 30.000 prebivalcev. Akcijski načrt za leti 2005 in 2006 pa med drugim vsebuje ažurnost katastrov, poenostavitev upravnih postopkov, kar sodi med izrazite upravne naloge, na drugi strani pa načrt vsebuje strateške.programske ukrepe, kot so priprava nacionalnega programa posodobitve državnih cest, posodobitev železniškega omrežja, izdelava izvedbenih aktov za zagotovitev dostopnosti javnega potniškega prometa, kar sodi $\mathrm{v}$ področje prometa.

Dovolj podatkov za sklepno besedo o STRATEGIJI SLO št. 1. Strategija je naravnana predvsem na področje gospodarstva, kar je zaslediti že iz uvodnih temeljnih ciljev ali pa iz priloge, kjer je med petimi razvojnimi prioritetami ponujena le »uresničljivost gospodarskega cilja strategije«. In za presojo na današnjem srečanju. Strategija razvoja Slovenije vnaša dodatno razcepljenost med že tako krhkim neravnovesjem med sprejetima strategijama o regionalnem in prostorskem razvoju. Dodatno pa politiko prostorskega (regionalno - prostorskega) razvoja degradira na vzpostavljanje evidenc in spodbujanje lokalne oskrbe s hrano! 


\section{EVROPSKI POGLEDI}

Padle so meje držav in leta 1999 je sprejel Svet ministrov odgovornih za regionalno planiranje držav članic EU »Evropske prostorske razvojne perspektive - EPRP« kot prvi skupni dokument bodoče skupne prostorske politike, ki s 1. majem 2004 zavezuje tudi Slovenijo (Evropske prostorske ..., 1999).

Ta dokument predstavlja razvojne smernice za nacionalne prostorske usmeritve in njihove sektorske politike, njegovo temeljno načelo glasi »prostor je treba obravnavati kot vir, ki je omejen in s katerim je treba ravnati trajnostno«. Trajnostni razvoj ne vključuje le okoljsko smotrnega gospodarskega razvoja, ki naj ohranja naravne vire za prihodnje generacije, temveč tudi uravnotežen prostorski razvoj. Le-ta se izkaže s tremi prostorsko razvojnimi cilji:

- policentričnem prostorskem razvoju in novim odnosom med mestnimi in kmetijskimi območji

- zagotavljanje enakovrednega dostopa do infrastrukture in znanja

- $\quad$ preudarno upravljanje ter varovanje naravne in kulturne dediščine.

In v letu 2000 so sledila še »Vodilna načela za trajnostni razvoj evropske celine» (Hannover, september 2000), ki jih je sprejela Evropska konferenca ministrov, odgovornih za regionalno planiranje - CEMAT, ki pod okriljem Sveta Evrope združuje 45 držav članic, med temi je tudi Slovenija (Vodilna ..., 2000).

Namen »Vodilnih načel« je uskladiti ekonomske in družbene potrebe območij z ekološkimi in kulturnimi funkcijami ter tako omogočiti uravnotežen prostorski razvoj na vseh ravneh.

V letu 2003 pa smo dobili še »Ljubljansko deklaracijo o prostorski razseženosti vzdržnega razvoja« (Ljubljana, september 2003, 13. CEMAT), ki poudarja, da je PROSTOR nosilna podlaga in okvir človekovega bivanja in dejavnosti ter zato osnova vzdržnega razvoja, ki ga tvorijo gospodarska, okoljska in družbena vzdržnost. Da bi dosegli te cilje je potrebno izboljšati prostorske razvojne politike, predvsem z uravnoteženim policentričnem razvojem evropske celine in nastajanjem funkcionalnih urbanih regij, s povečanjem učinkovitosti prometnih in energetskih omrežij, revitalizacijo naselij in izboljšanju razvrednotenega okolja (Ljubljanska ..., 2003).

Za naše razmere so poučna opozorila, ki so jih izrekli udeleženci mednarodnega seminarja kot spremljevalnega dogodka 13. CEMAT (17-18 september Maribor). »Posledice širitve EU«, med drugim: »dokler bo EU le klub bogatih držav, si v odsotnosti prostorskega načrtovanja na evropski ravni lahko privoščimo neučinkovitost pristopov regionalne politike« (Posledice ..., 2003).

Ob zaključku se je direktor Inštituta za regionalno planiranje, Univerze v Stuttgartu odzval kar kritično, na »odločitev organizatorja (MOPE) da se namesto na inštrumente prostorskega razvoja osredotoči na inštrumente prostorskega načrtovanja, ki predstavljajo le del inštrumentov prostorskega razvoja«. »Domnevamo lahko, da nas večina, vsaj načelno, soglaša o tem in da bomo vse bolj opuščali tradicionalen način prostorskega načrtovanja $\mathrm{z}$ izdelavo zemljevidov v 7 barvah, ki so primerni za dekoracijo pisarniških prostorov načrtovalcev, nimajo pa vplivov, na spremembe v realnem svetu«. Seveda brez grafičnih prikazov ne gre, 
ampak le kot nazoren prikaz usklajenih načrtov za posege v prostor, ne pa kot zarisi monopolnih interesov na nekem območju.

\section{KAKO POTEKAJO SPREMEMBE PROSTORSKE DOKTRINE PO DRŽAVAH}

- $\quad$ Avstrija: Za usklajevanje sektorskih programov s politiko prostorskega razvoja skrbi poseben organ »Avstrijska konferenca o prostorskem planiranju - OROK«, njeni člani so zvezni kancler, zvezni ministri, deželni glavarji, predstavnika združenj lokalnih skupnosti. Kot svetovalci pa sodelujejo predstavniki socialnih partnerjev na zvezni ravni (delavska zbornica, gospodarska zbornica, sindikati in drugi).

- Nemčija: Spreminja paradigmo, iz tradicionalnega urejanja prostora (Raumordnung) prehaja v prostorsko razvojno politiko (Raumentwicklungspolitik)

- Irska: Pri pripravi Strategije prostorskega razvoja je vlada Irske dala poudarke na spodbujanju visoke ravni javne zavesti in soglasja javnosti o novih usmeritvah, na podporo za vzajemno politiko med vladnimi resorji, regionalnimi oblastmi in na strokovne osnovecelovite prostorske analize na državni ravni. Ob sprejetju se je vlada Irske odločila, da se morajo vse prostorsko pomembne politike in programi javnega sektorja skladati z državno prostorsko strategijo. V podporo tej odločitvi so vzpostavili mehanizme na ravni države, sektorjev ter na regionalni in lokalni ravni, postopki vključujejo preglede obstoječih politik do ugotavljanja, kako bi z naložbenimi vlaganji podprli izvajanje Državne prostorske strategije (Posledice ..., 2003).

Ali se drznemo primerjati, pod kakšnimi pogoji naj bi se uresničevala Strategija prostorskega razvoja Slovenije?

\section{MOČ IN NEMOČ URESNIČEVANJA REGIONALNO - PROSTORSKEGA RAZVOJA V SLOVENIJI}

\section{Vrzeli nove prostorske zakonodaje}

Za Strategijo prostorskega razvoja Slovenije lahko rečemo, da je načeloma pripravljena $\mathrm{v}$ skladu z izhodišči na evropski ravni, ostane vprašanje uresničevanja: ali kotira prostorska politika dovolj visoko na državni ravni, ali ima podporo na sektorski in občinski ravni in $\mathrm{v}$ javnosti, in vprašanje ali lahko ponujeni inštrumenti za uresničevanje zagotovijo učinkovitost izvajanja sprejete strategije, ki ima svoj »deficit« že v (ne)določilh v letu 2002 sprejetega Zakona o urejanju prostora.

Prostorske sestavine družbenih planov so veljale še deset let po ukinitvi sistema družbenega planiranja, ki je degradiral strateške odločitve o urejanju prostora - prostorske plane na raven lokacijske dokumentacije. Pri vsej visoki politiki, odgovornosti Vlade RS, predvsem pa resornega ministrstva je moralo poseči celo Ustavno sodišče, z ugotovitvijo, da je zaradi nepopolnosti in ohlapnosti vprašljiva pravilnost in zakonitost posameznih izvedbenih prostor- 
skih planov in da določbe o prostorsko ureditvenih pogojih niso prirejene za večje posege $\mathrm{v}$ prostor, občine pa to pravno praznino zapolnjujejo s samosvojimi strokovnimi rešitvami, ki dejansko pomenijo spremembo prostorskih ureditvenih pogojev mimo javnih razgrnitev in obravnav, v škodo javnih in skupnih koristi (Geodetski vestnik, 2004).

Nov zakon o urejanju prostora, naj bi tudi poenostavil postopke izdelave in pridobivanja dovoljenj za posege $\mathrm{v}$ prostor. Na znanstvenem simpoziju ob 30-obletnici IPŠPUP-a - 2004, smo v prispevku Rakar Albina in Krofl Mateje lahko prebrali, »da je bil cilj predlagateljev zakona liberalizacija urejanja prostora, ne pa njegova večja determiniranost« in nadaljujeta..., »da lahko le sklepamo, da bodo lokalne skupnosti praznino $\mathrm{v}$ prostorskih redih zopet zapolnjevale - TOKRAT SKUPAJ Z INVESTITORJI - z nekaterimi »svojimi rešitvami«, seveda umaknjeno od oči javnosti (laične in strokovne)« (Prostorske ..., 2004, str. 184); gre za novo zakonsko možnost o sklenitvi urbanistične pogodbe med investitorjem in občino. Na istem simpoziju pa je Marjan Ravbar posledice zakonskega deficita za izvajanje prostorske politike ocenil z besedami, »da zakon ne nudi dovolj opore za preprečitev načrtov - agresivnim zahtevam različnih ekonomskih in političnih akterjev, ki pod krinko globalizacijskih procesov in svetovnega gospodarstva (praviloma) vedno bolj uspevajo doseči svoje cilje na za njih najbolj ustreznih zemljiščih«. (Prostorske ..., 2004, str. 94) Spomnimo se pritiskov za nove turistične cone na naravnih območjih (Bohinjsko jezero) ali pa za stanovanjsko-poslovne cone v mestih (Ljubljana - Stožice).

\section{Medsektorska in sektorska raven}

V Sloveniji smo se razvadili, da »makro-uporabniki prostora, predvsem s področja infrastrukture, kmetijstva, turizma, »izsiljujejo« svoje programe in projekte, povezane s finančnimi interesi, prek prostorskih ureditev od strategij, prostorskih redov do lokacijskih načrtov. Pristope iz obdobja samoupravnih interesnih skupnosti so uspeli podaljšati v razvojnih programih, ki so jih bodisi Vlada RS bodisi Državni zbor RS sprejeli v obdobju po letu 1992. Strategija prostorskega razvoja sicer vsebuje poglavje »Ukrepi za izvajanje prostorske strategije«, ki obsega aktivnosti za zagotavljanje skladnosti razvojnih aktov in prostorskih aktov, kar naj bi se izvajalo v sodelovanju pristojnih ministrstev z ministrstvom, pristojnim za okolje. V primeru ugotovljene neskladnosti pa odloča Vlada RS. V objavljenem ODLOKU O STRATEGIJI PROSTORSKEGA RAZVOJA SLOVENIJE so tudi določila, da z dnem uveljavitve prenehajo veljati prostorske sestavine dolgoročnega plana SR Slovenije 19862000 in Srednjeročnega družbenega plana SRS 1986-1990, ni pa določila, da je potrebno po letu 1992 sprejete razvojne sektorske programe preveriti in po potrebi dopolniti oziroma spremeniti (Strategija ..., 2004).

Takšen postopek predvidevata oba evropska dokumenta EPRP in CEMAT in za takšno pot se je davnega leta 1973 odločila takratna Skupščina SR Slovenije ob sprejemu prvega elementa regionalnega prostorskega plana. (Poglavitni smotri in smernice za urejanje prostora), s katerim je zavezala takratno vlado (IS SRS), da je za izvajanje prostorske politike med drugimi potrebno:

- $\quad$ uskladiti obstoječe republiške sektorske predpise oz. izdati nove, glede na sprejete smernice 
- $\quad$ sprejete smernice upoštevati pri izdelavi programov in projektov na področjih prometa, energetike, vodnega gospodarstva, stanovanjske gradnje, industrije, kmetijstva, gozdarstva, turizma in družbenih dejavnosti (šolstva, zdravstva, kulture) ter uskladiti tudi investicijske pobude

- $\quad$ končno, naj banke upoštevajo sprejete smernice pri oblikovanju in izvajanju kreditne politike. (Vir 3)

V Strategiji prostorskega razvoja so sicer določila o postopkih, če pride do odstopanj pri izdelavi sektorskih programov, najprej MOP z resornimi ministri, končni »arbiter« pa je Vlada RS. Lahko pa se vprašamo ali je strokovna služba v MOP (Urad RS za prostorsko planiranje) na ustrezni ravni v hierarhiji strokovnih služb. Urad je »enakopraven« partner S strokovnimi enotami $v$ resornih ministrstvih, $v$ odnosu do resorne službe za regionalni razvoj pa je na nižji stopnički: »najšibkejši člen«. Nekdanja Agencija za regionalni razvoj (1995) je iz organa v sestavi Ministrstva za gospodarstvo prešla v Službo Vlade RS za strukturno politiko in regionalni razvoj. Strokovna služba za prostorski razvoj, prvotno v sestavi Republiškega sekretarijata za urbanizem (1968), se je izvila iz primeža tekoče politike in prešla v Zavod SR Slovenije za regionalno prostorsko planiranje (1973) - na raven vladnega organa in se je po agonijah v sistemu družbenega planiranja v letu 1992 vrnila v »izhodiščni položaj« kot »pod - organ« v sestavi Ministrstva za okolje in prostor.

\section{Regionalni in prostorski ni regionalno-prostorski razvoj}

Predpisi o načrtovanju gospodarskega razvoja so postali preteklost $\mathrm{z}$ ukinitvijo sistema družbenega planiranja, regionalno in prostorsko planiranje, pa je ostalo vsaka na svojem bregu, čeprav imata skupno osnovo v policentrični poselitveni zasnovi, malce sramežljivo ju združuje določilo 51. člena Zakona o urejanju prostora, ki predvideva možnost sočasne priprave regionalne zasnove prostorskega razvoja in regionalnega razvojnega programa.

Imamo: dva zakona, dve strategiji, dve strokovni službi, dva ministra. V Sloveniji smo razdeljeni na občine in statistične regije, po kriteriju EU pa bomo pristali v eni ali največ dveh regijah. Vendar naše slovenske regije potrebujemo ne glede na evropska merila, potrebujemo jih zaradi uresničevanja (in tudi oblikovanja) sprejetih strateških državnih usmeritev na vseh območjih, tudi na lokalni ravni. Ali je to tistih 12-14 upravnih regij, ki so jih pred leti terjali župani 33 občin ali pa tiste iz obdobja oblikovanja regionalno-prostorskega plana ispred 30-tih let, ki jih je takratna vlada (IS SRS) »požegnala« - pa saj so enake! Resnično potrebujemo most med državo in njenimi 58-timi upravnimi enotami ter 193-timi občinami. Večina evropskih držav iz območja EU je vzpostavila regijske planske zveze prek katerih se vsklajujejo interesi na teritorialnih ravneh, poznamo tudi planske dosvete, kjer sedijo za isto mizo predstavniki gospodarskih in družbenih dejavnosti ter tudi predstavniki civilne družbe - nevladnih organizacij.

ALI ZMOREMO V MINISTRSTVIH (resorjih) vzpostaviti interdisciplinarne strokovne službe, da bi se sektorski pogledi lahko že v »lastni hiši« soočili s socialnimi, prostorskimi, regionalnimi in okoljskimi pogledi.

ALI ZMOREMO SPREJETI OBNAŠANJE DRŽAV - ČLANIC EU in sprejeti samo en planski dokument »Strategijo regionalno-prostorskega razvoja«, ki bi ga pripravil »nov« 
urad Vlade RS za to področje in bi jo sestavljali:

- $\quad$ skupni cilji zlasti za varovanje naravnega življenskega okolja, razvoj podeželja, predvsem manj razvitih območij, zagotavljanje funkcij v urbanih okoljih, izgradnjo infrastrukture,

- $\quad$ sektorski cilji zlasti za razvoj kmetijstva, gozdarstva, turizma in drugih področij

- $\quad$ investicijske namere v skladu s cilji državnega razvojnega programa in po kriterijih za pridobivanje pomoči iz strukturnih skladov EU.

S to potezo bi lahko začeli uresničevati povezovanje gospodarskega in prostorskega razvoja na vseh ravneh, od državne, regionalne do občinske, pa tudi urbano in ruralno politiko $\mathrm{v}$ celovito politiko regionalno-prostorskega razvoja naše države.

MAR SE RES NE ZAVEDAMO, da moramo pravočasno pripraviti skupen enoten odgovor na posledice širitve Evropske unije - po ukinitvi meddržavnih mej. Spremenila se bo vloga urbanih središč ob današnjih mejah in obstoječih prometnih povezav - prometni tokovi se bodo okrepili - povečala se bo težnja po skupnih zavarovanih območjih, tudi po skupnem načrtovanju turističnih območij, soočili se bomo z zahtevami za skupen nadzor onesnaževanja okolja in ohranjanja krajine. Skratka, politične spremembe zadnjih let so v državah-članicah že sprožile pomembne spremembe, ki se odražajo v novi evropski prostorski strukturi, na vrsti je Slovenija.

\section{SKLEP}

O navedenih razhajanjih lahko iz leta v leto prebiramo opozorila in predloge za vzpostavitev evropskega modela. Pojavljajo se v dnevnem tisku, strokovnih glasilih, predvsemiz geografskih vrst. Zaradi časa in okolja srečanja bom navedel le besede, ki jih je o regionalnem razvoju objavil že pred petimi leti naš jubilant, med drugim: »da pogosto ni jasno, v kateri resor $\mathrm{v}$ državni upravi uvrstiti regionalno razvojno politiko, da vkljub svoji socialekonomski zasnovi pomeni aktivno poseganje $\mathrm{v}$ prostor iz česar sledi, da je regionalna razvojna politika nekakršna vez med socioekonomskimi stremljenji družbe in konkretnim prostorskim urejanjem « in zaključuje $\mathrm{z}$ opozorilom »da regionalna razvojna politika ne uživa velike naklonjenosti, $\mathrm{v}$ vladni gospodarski politiki je pogostoma nekakšen »nepotreben appendix «, prostorski planeri pa je tudi ne sprejemajo za svojo, imajo jo za podaljšek politike, tuja jim je njena obravnava prostora kot ekonomskega in socialnega dejavnika« NI KAJ DODATI!

In v razmislek organizatorju našega strokovnega srečanja. Po osnovni izobrazbi izhajam iz geodetskih krogov, kjer se lomijo kopja med izobraževalno sfero in prakso. Predsednik Mednarodne zveze geodetov - FIG prof.dr.Holger Magel je na lanskoletnem mednarodnem srečanju geodetov takole svetoval: »Na fakulteti morate določiti svoje izobraževalne, strokovne in družbene naloge. Fakulteta mora postaviti jasne cilje, še bolj pomembno pa je, da medije in javnost seznani s svojimi cilji in nameni. Ključno je, da ima fakulteta svoj moto. $\mathrm{Ob}$ pomembnih obiskih politikov in ekonomistov je te treba seznaniti z motom fakultete. Moto je najbolj preprost in učinkovit način, da predstavite delovanje znotraj fakultete in da se predstavite zunanjemu svetu. Seveda se mora vaše delovanje podrejati motu, sicer bodo vaši cilji in naloge zamujali, v najslabšem primeru pa bodo zgrešeni« (Geodetski ..., 2004). 
Njegove besede se da razumeti tudi takole: Odgovornost Univerze ni zgolj v izobraŽevanju, spremljati in vplivati mora, da se bo pridobljeno znanje prelilo v prakso. Sem bil dovolj jasen?

\section{Literatura}

Državni razvojni program Republike Slovenije 2001-2006. Povzetek predloga, Ministrstva za gospodarstvo, Ljubljana, 2002.

Evropska konferenca ministrov pristojnih za regionalno prostorsko planiranje - Svet Evrope, Strassboug, 1973

Evropske prostorsko razvojne prspektive - EPRP. EU - ministrska konferenca držav članic EU, Postdam, 1999.

Geodetski vestnik št. 48/4, st. 502, Ljubljana 2004.

Ljubljanska deklaracija o prostorski razsežnosti vzdržnega razvoja. 13. konferenca CEMAT, Ljubljana 2003.

Posledice širitve EU. Zbornik mednarodnega seminarja - 13. konferenca CEMAT, Maribor, 2003.

Prostorske znanosti 21. stoletje. Jubilejni zbornik IPŠPUP, Oktober 2004.

Resolucija o poglavitnih smotrih in smernicah za urejanje prostora. Skupščina SR Slovenije (Ur.l. SRS št. 43), Ljubljana, 1973.

Strategija regionalnega razvoja Slovenije 2001-2006. Državni zbor RS, Ljubljana, Poročevalec DZRS, št. 60, 9.7. 2001.

Strategija prostorskega razvoja Slovenije. Ur.l. RS št. 36/04, Ljubljana, 2004.

Strategija razvoja Slovenije. Vlada RS, Urad RS za makroekonomske analize in razvoj, Ljubljana, 2005.

Ustavno sodišče RS - Ur.l. RS, 15. marec 2004.

Vodilna načela za zagotavljanje trajnostnega prostorskega razvoja evropskega kontinenta. Evropska konferenca ministrov za regionalno planiranje Sveta Evrope - CEMAT, 12. konferenca, Hannover, 2000 Združeni narodi, E /CN.5/ 467 - Rev.1, New York, 1964

\section{REGIONAL AND SPATIAL PLANNING OR REGIONAL-SPATIAL PLANNING \\ Summary}

The XIX century industrialization and the related expansion of settlements and cities caused the development of planning at the economic and social field, as well as the development of urban planning. The growing pressure to link the new urban and vacant country areas, dictated the needs to plan the land use of the entire areas of particular states, from the economicsocial aspects within the limited conditions of physical land use and from the aspects of environmental protection claims. 
In the second half of the previous century European states acceded to the elaboration of regional-spatial plans, Slovenia did so in the year 1968. In the period before 1975 professional expertise was elaborated; the National Assembly of Slovenia adopted the first element $\gg$ basic aims and guidelines for spatial planning in the year 1973, and a year later, the Executive Council of Slovenia adopted the draft of the next element »The Concept of urbanization«, as key projection of regional-spatial development of the Republic and its regions. These documents were presented in a public debate. In the year 1975, the Institution for regionalspatial planning published in professional expertise the next and also the last element »Concept of land use regionalization«.

Introduction of social panning in the system of self-management joined economic, social and spatial aspects of the development at a very general direction level, and decisions about concrete development projects and investments were adopted by the so-called selfmanagement communities of interests. With the adoption of Constitution of Slovenia in the 1991 the social system of planning was abolished. In 1993 the government delimitated regional planning to economic and spatial planning, which influenced the two-tire system. In the period before 1999 government adopted all the basic sector programmes for social and infrastructure activities - systems. In the field of spatial development, however, directions from the period of social planning were extended in spite of efforts of responsible professional institutions. It was not until 2002 that the Parliament - with a ten-year delay - adopted the Spatial planning act and, two years latter, the Strategy of spatial development, but both with unfinished system, which lead to professional controversial decisions.

Apart from the strategy of spatial development, as a national starting point for the development of separate spatial systems, Slovenia adopted the National development programme in 2001, which was determined as a strategic economic development document and Strategy of regional development, and thus proposed as an instrument for the implementation of regional policy of the economic sector. Only recently in June, 2005 the Parliament adopted the Development strategy (draft proposal was presented more than a year before) as the principal strategic document of development of the new state, on which all other strategies and programmes of infrastructure systems, social activities and economy, should be based.

Even solely progressions of adoption of the planning documents, and even more conflicts between development priorities, above all between regional and spatial, is digressing us from the directions which were adopted by EU in the period 1999 - 2003: inseparability of spatial planning and regional development. 